\title{
Dayak Meratus Tribe in The Middle of Modernity in Eva Liana's Novel 'Mawinei': A Cultural Transformation
}

\author{
Derri Ris Riana ${ }^{1}$, Indrawati ${ }^{2}$, Dede Hidayatullah ${ }^{3}$ \\ \{derri.ris@kemdikbud.go.id ${ }^{1}$,indra_bhs73@yahoo.co.id ${ }^{2}$, dayatdh@gmail.com ${ }^{3}$ \} \\ Balai Bahasa Provinsi Kalimantan Selatan, Jalan Jenderal Ahmad Yani Km. 32, Loktabat, \\ Banjarbaru $70712^{1,2,3}$
}

\begin{abstract}
The modernization has an impact on the Dayak Meratus Tribe. Traditions that are firmly held begin to slowly falter due to the influence of capitalism and interactions with the outside world. This study aims to describe the cultural transformation in Dayak Meratus tribe in the novel Mawinei by Eva Liana, as well as to describe the supporting factors and challenges in the process of cultural transformation. This study uses a qualitative descriptive method using a literary anthropological approach. Koentjaraningrat's theory is used to find cultural elements to explore the cultural transformations. There are transformations of living equipment and technology systems, knowledge systems, livelihood systems, and religious systems. The internal factors are the willingness to overcome life's problems and rejection of tradition. Meanwhile, external factors are modernization and the influence of Islam. The cultural transformation is caused by the strength of traditions by some people and the rejection of new beliefs.
\end{abstract}

Keywords: Meratus Dayak-1; cultural transformation-2; modernization-3 


\section{Introduction}

The development of global communication and information at this time affects people in various aspects of life. The people are not only those who live in big cities, but also the Dayak Meratus tribe or called the Dayak Bukit tribe who live in the interior. The Dayak Meratus tribe has characteristics, namely living in a balai/long house; believe in animism/dynamism; livelihoods dependent on nature, such as hunting and farming; and stick to customs. However, at this time when modernization hit the life of the Dayak community, there was a cultural transformation. The efforts of the Dayak Meratus tribe who have strong customs in responding to this phenomenon are interesting to study, especially the cultural transformation happened due to the development of modernization and interaction with the world.

The Dayak Meratus tribe is identical to the interior tribes. This tribe that is close to nature is a tribe that lives in the Meratus Mountains area, South Kalimantan. For them, nature is not only a place to live, but also an inseparable part of culture. Therefore, Dayak Meratus culture is inseparable from nature and nature is their main resource [1]. In terms of religion/belief, they adhere to animism/dynamism which worships ancestral spirits by performing traditional ceremonies which are identical with kaharingan [2]. Various ceremonies are carried out utilizing the natural wealth around their residence, the belian ceremony to heal the sick, for example, using various herbs from the plants that grow around them [3]. The livelihoods of most of the Dayak Meratus people rely on nature, for example hunting, farming, gardening, and raising livestock. The system of knowledge and technology that develops in the Meratus Dayak community is also related to nature. The culture of living and developing in the Meratus Dayak tribe is passed down from one generation to the next. However, along with the times, the Dayak Meratus identity, which is rich in customs and does not know the outside world, gradually begins to fade. The current of modernization has begun to touch Meratus culture. Wealth of natural resources began to be explored in the form of the entry of timber companies, coal mining, and palm oil. The influence of modernization also permeates the culture of the people, which makes the old change the traditional to the modern. Gradually, but surely there has been a cultural transformation.

Culture represents the mindset, behavior, and actions of the people, as well as the culture of the Dayak Meratus which describes the unique characteristics of its people. Kluckhohn states that culture is community knowledge stored in human memory, both in books and objects [23]. This culture has become part of the life of the Dayak Meratus community. The cultural values cannot be released even if members of the community leave the community. Kluckhohn divides culture into 11 characteristics, which are related to the way of life of humans as a whole; the individual's social legacy obtained from his community; ways of thinking, feeling, and believing; action abstraction; the way community groups behave; where humans in society learn together; a standardized set of orientations on a problem; a set of techniques for regulating both the external and internal environment; and the history section [24]. 
The richness and exoticism of culture, as well as the transformation of Dayak Meratus culture can be shown in the novel Mawinei by Eva Liana. This novel tells the story of the main character named Mawinei who comes from the Dayak Meratus tribe. In the midst of unfavorable environmental conditions in terms of access to education, Mawinei figures struggle to pursue education up to higher education. Mawinei aspires to become a doctor who will be able to help and change the condition of the people who have been left behind. On the way, Mawinei had an accident during a forest fire. It was then that she met Aisyah's mother. Aisyah's mother, who had just lost her beloved daughter, thought of Mawinei as her own child. After recovering, Mawinei, who at that time lost her memory, was taken and cared for by Ibu Aisyah like her own child so that she left the Dayak Meratus environment. Mawinei, who has lived in the Dayak Meratus community since childhood, had difficulty adapting to the new environment. Slowly Mawinei accepted her condition and began to adapt. She continues to fight tirelessly to get a doctor's degree. After becoming a doctor, she returned to her hometown in Meratus and devoted herself fully there. This novel features the character Mawinei, a representation of the Dayak Meratus character who has received external influence after studying and interacting with people outside the Dayak Meratus. She also experienced a change in the knowledge system and a more modern mindset. This outside influence has formed a new Mawinei which at first was not fully accepted by the Dayak Meratus community. However, there is a gradual transformation of the Meratus Dayak culture that occurs as a result of the interaction with the outside world and the influence of modernization.

The existence of cultural values that have been firmly held by the Dayak Meratus tribe is slowly undergoing a transformation. Cultural values are guidelines for life adopted by the community. Cultural transformation occurs when a culture experiences a shift due to the entry of foreign cultures. The shift does not change the existing culture as a whole, but affects and changes some aspects of the culture. The change did not happen suddenly, but slowly. Influence from outside is not directly accepted, but through the process of acculturation in the form of adjustments to the culture that has existed before. At first the external influence experienced rejection from the people who still adhered to the existing culture. However, gradually it can be accepted with open arms with the penetration and understanding of the incoming culture. The Dayak tribe has a distinctive cultural identity. In general, where the Dayak tribe lives in the interior, not in coastal areas [25]. The Dayak tribe is also characterized by living in long houses, animistic religion, and a moving life. However, the cultural identity has changed [26]. 
This novel is interesting to study because it describes the cultural transformation of the Dayak Meratus Tribe. So far, the Dayak Meratus tribe adheres to cultural values that can be seen from the seven universal cultural elements in it, including social systems, knowledge and technology systems, equipment systems, language, livelihoods, arts, and religious systems. However, slowly these values underwent a transformation. Therefore, this study aims to describe the cultural transformation that occurred in the Meratus Dayak tribe and describe the supporting factors and challenges in the process of cultural transformation in the novel Mawinei by Eva Liana. The transformation of cultural values that occurs in the Dayak Meratus tribe is explored from universal cultural values, namely language, technological systems, economic systems, social organizations, knowledge systems, arts, and religious systems [29]. In order to understand the extent of the cultural transformation, it is necessary to analyse deeper into the supporting factors and challenges in the transformation process. Supporting Factor of cultural transformation is related to internal factor that comes from the Dayak community itself which goes to an easy transformation, and external factor that supports the transformation. Meanwhile, the challenges of cultural transformation relate to cultural aspects that hinder the transformation process.

The cultural transformation of the Dayak Meratus Tribe can be seen through the novel Mawinei by Eva Liana. This research is included in the study of literary anthropology because it understands literature by studying culture. Literary anthropology tries to trace the anthropological characteristics of literary works from their narratives that describe human behavior in them [27]. Therefore, literary works reflect the cultural aspects expressed by the author through the description of human life in each character. The relationship between literature and culture is caused by three things, namely writers live in various cultural contexts, full of challenges, and sometimes tempting; it is impossible for writers to be sterile from environmental influences, patterned cultural imitation; and writers become connectors for cultural regeneration so that inheritance occurs [28]. Literary works reveal the cultural aspects expressed by the authors in their environment. 
Many studies related to cultural transformation have been written to look at the cultural transformations that occur in certain societies. This research is usually field research such as research on the religious system of the Dayak Meratus people with traditional equipment [4] ethnomedicine used in medicine [3]; balian and mystical medicine [5] [6]; language [7] [8]; and cultural system [9] [10]. In addition, there is also research on the Meratus Dayak in the novel such as that conducted by Indrawati [11] which explores the locality of the language in the novel; and an anthropological study of the rituals of the Banjar and Meratus Dayak people from Miranda and Avesina's novel Jendela Seribu Sungai by Miranda and Avesina [12]. The research entitled "Transformation of Cultural Values in the Novel Under the Same Sky by Helga Rif (Literary Anthropology Approach)" [13] explores cultural transformation in the form of maintaining cultural values and changing cultural values. Transformation research was also conducted to look at the role of women in India in the novels by Bankimchandra chattopadhyay [14] and also the development of cultural change in the pre-independence period in Sri Lanka [15]; political and cultural changes in Muslims in Sri Lanka [16]; to see cultural differences in the feminine perspective in a male-dominated world [17]; unraveling the literary representation of the transformation of the sexual identity of an Asian migrant in Australia in the novel behind the Moon [18]; measuring the change in the value of a person's social honor in Europe in 20 European novels [19]; see the transformation of traditional culture that is dynamic and conflicting, but more or less stable when influenced by colonialism in Chinua's novel Things Fall Apart [20]; the role of the author and his work in promiscuity in the Netherlands in the 1960s_-1970s [21]. Other research related to cultural transformation is also contained in an article entitled "Gender Perspectives and Cultural Transformation in Indonesian Novels with Local Colors of Java" [22]. This paper describes the cultural transformation that occurs in the character of Javanese women who not only play a role in the domestic sphere, but also in the public sphere. These studies have described cultural transformation, but have not explored further the supporting factors and challenges in the transformation process. In fact, it is necessary to explore the process of cultural transformation. Furthermore, Mawinei's novel has never been explored further related to the topic of cultural transformation of the Dayak Meratus tribe depicted in the novel.

\section{Method}

This study uses a literary anthropological approach. Literary anthropology examines literary works as an expression of the diversity of humans and their culture through the description of the characters in the story [30]. By using this approach, the cultural transformation of the Dayak Meratus tribe is explored in a literary work, namely the novel Mawinei. The literary work used as the primary data source is the novel Mawinei by Eva Liana which was published by the Zukzez Express publisher in 2017. Meanwhile, the secondary data source is other references related to the culture of the Dayak Meratus, both in the form of books and scientific articles. The data used are in the form of sentences or paragraphs in the Mawinei novel which contains cultural values and the cultural transformation of the Dayak Meratus Tribe. The data analysis technique was carried out in several stages, namely:

1. record and classify data on cultural transformation in Mawinei's novel fragments based on elements of universal culture, namely language, technological system, economic system, social organization, knowledge system, art, and religious system; 
2. analyse data by exploring the forms of cultural transformation of the Dayak Meratus Tribe; supporting factors for cultural transformation, both internal and external factors; and challenges in the process of cultural transformation; and

3. conclude the results of the analysis to describe the cultural transformation of the Dayak Meratus, as well as the supporting factors and challenges in the transformation process.

\section{Result}

From the novel Mawinei by Eva Liana, there are cultural transformations of the Dayak Meratus tribe, namely the transformation of religious systems, knowledge systems, livelihood systems, and technology systems. The process of cultural transformation occurs because there are supporting factors, both internal and external from the Dayak Meratus community. The challenges that hinder the transformation process are also explored in Mawinei's novel. The description of the cultural transformation of the Dayak Meratus Tribe, as well as the supporting factors and challenges of the cultural transformation can be seen as follows.

\subsection{Cultural Transformation}

There has been a cultural transformation of the Dayak Meratus Tribe, namely language, technological systems, economic systems, social organizations, knowledge systems, arts, and religious systems as described in seven universal culture [29], not all have been transformed. Based on the data obtained, there has been a transformation of religious systems, knowledge systems, livelihoods, and technology systems. . The forms of cultural transformation contained in the novel Mawinei by Eva Liana are presented in the following table.

Table 1. Cultural Transformation of Dayak Meratus Tribe in the Novel Mawinei

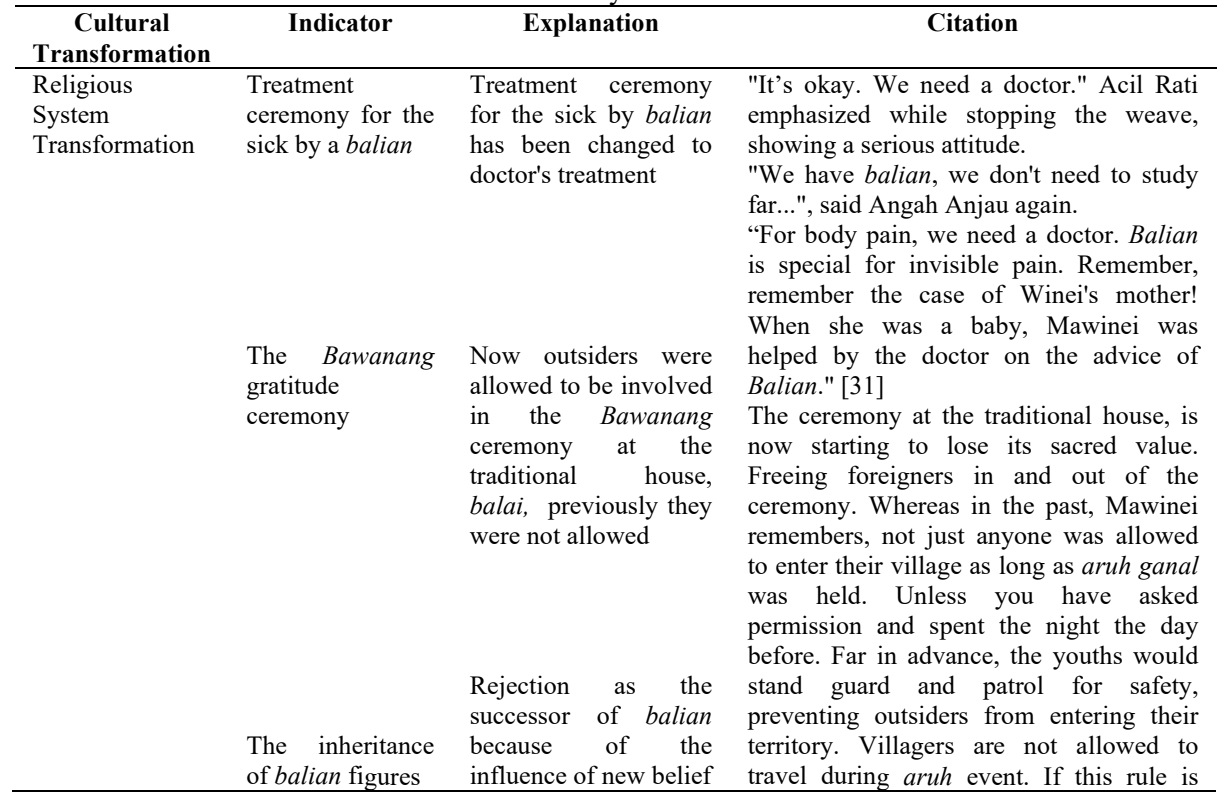




\begin{tabular}{|c|c|c|c|}
\hline $\begin{array}{c}\text { Cultural } \\
\text { Transformation }\end{array}$ & Indicator & Explanation & Citation \\
\hline & $\begin{array}{l}\text { Behavioral } \\
\text { changes in beliefs }\end{array}$ & $\begin{array}{l}\text { Behavioral changes in } \\
\text { beliefs to leave a } \\
\text { culture that is not in } \\
\text { accordance with their } \\
\text { current beliefs }\end{array}$ & $\begin{array}{l}\text { broken, they believe that disaster, death or } \\
\text { disease will happen [31]. } \\
\text { "Geez, Awat. Please forgive me profusely. } \\
\text { I'm actually flattered by the trust that was } \\
\text { bestowed upon me since childhood. } \\
\text { However, the customary principle can no } \\
\text { longer be carried out. So... I can't afford } \\
\text { to take this position. Even though Awat } \\
\text { considers myself to be the chosen one, my } \\
\text { faith cannot be neglected [31]. } \\
\text { "Burning these amulets, Ni!" said } \\
\text { Mawinei without stopping his action. } \\
\text { "No, Mawinei! Don't do that, you'll get } \\
\text { the consequence! Pamali, Pamali! } \\
\text { Goddamn it!" Bidayuh screamed as she } \\
\text { tried to catch his granddaughter's hand to } \\
\text { prevent the burning that bled his heart } \\
\text { [31]. }\end{array}$ \\
\hline $\begin{array}{l}\text { Knowledge } \\
\text { System } \\
\text { Transformation }\end{array}$ & $\begin{array}{l}\text { The change of } \\
\text { mindset of the } \\
\text { characters who } \\
\text { no longer adhere } \\
\text { to tradition due to } \\
\text { the development } \\
\text { of their } \\
\text { knowledge and } \\
\text { modernization }\end{array}$ & $\begin{array}{l}\text { Rejection of the } \\
\text { arranged marriage } \\
\text { tradition and married } \\
\text { at a young age because } \\
\text { of pursuing higher } \\
\text { education }\end{array}$ & $\begin{array}{l}\text { "Grandpa, I can't live up to your } \\
\text { expectations! I refuse this matchmaking!" } \\
\text { Lonely. No reply was heard. Even the } \\
\text { wind died, reluctant to make a sound. } \\
\text { Everyone was shocked. The young girl } \\
\text { had dared to break the rules of the damang } \\
\text { they respected in front of all the guests. } \\
\text { Damang whose supernatural powers shake } \\
\text { the earth, shake the sky. A shrewd Dayak } \\
\text { swordsman and skilled in Mandau } \\
\text { knowledge with unexpected powers, } \\
\text { terrifies his opponents. His leadership } \\
\text { abilities and wisdom are unquestionable. } \\
\text { Not a single one dared to argue, if this } \\
\text { magic damang willed. That's why, it really } \\
\text { makes blood boil, seeing the recklessness } \\
\text { of a teenager, against the will of the tribal } \\
\text { chief, who incidentally is her own } \\
\text { grandfather [31]. } \\
\text { "But Grandma Lamiang's concoction is } \\
\text { also effective," said Angah Anjau. } \\
\text { "The problem is, none of us have inherited } \\
\text { Grandma Lamiang's medical knowledge to } \\
\text { an advanced level. If Grandma Lamiang } \\
\text { dies, who will replace her? So far, only } \\
\text { Mawinei is comfortable and willing to } \\
\text { memorize the recipe." [31] }\end{array}$ \\
\hline $\begin{array}{l}\text { Livelihood } \\
\text { System } \\
\text { Transformation }\end{array}$ & $\begin{array}{l}\text { Dayak Meratus } \\
\text { people have } \\
\text { switched to other } \\
\text { jobs }\end{array}$ & $\begin{array}{l}\text { The jobs that can } \\
\text { fulfill the needs of } \\
\text { people's lives }\end{array}$ & $\begin{array}{l}\text { According to her teacher, Setiawan, if you } \\
\text { want to be smart in helping and treating } \\
\text { sick people, you must become a doctor. } \\
\text { Not balian. To become a doctor, you have } \\
\text { to go to college. College costs a lot. The } \\
\text { cost is similar to the value of the harvest of } \\
\text { ten bulk of rice fields per year. If her } \\
\text { performance is good, then Mawinei can } \\
\text { get an achievement. But the cost of } \\
\text { boarding, eating, drinking and college } \\
\text { needs, borne by yourself. }\end{array}$ \\
\hline $\begin{array}{l}\text { Equipment and } \\
\text { Technology }\end{array}$ & $\begin{array}{l}\text { The influence of } \\
\text { modernization, }\end{array}$ & $\begin{array}{l}\text { The long house is in } \\
\text { the form of a house on }\end{array}$ & $\begin{array}{l}\text { Si Balwin, Lida and Sarita are married and } \\
\text { each have one child. While Rimbun, }\end{array}$ \\
\hline
\end{tabular}




\begin{tabular}{|c|c|c|c|}
\hline $\begin{array}{c}\text { Cultural } \\
\text { Transformation }\end{array}$ & Indicator & Explanation & Citation \\
\hline \multirow[t]{3}{*}{ Transformation } & $\begin{array}{l}\text { the equipment } \\
\text { and technology } \\
\text { systems of the } \\
\text { Dayak Meratus } \\
\text { have changed }\end{array}$ & $\begin{array}{l}\text { stilts inhabited by } \\
\text { dozens of families, but } \\
\text { nowadays they choose } \\
\text { to build their own } \\
\text { house } \\
\text { The change of dress } \\
\text { style of the young } \\
\text { people that tends to } \\
\text { follow the current } \\
\text { trends. }\end{array}$ & $\begin{array}{l}\text { getting taller and beautiful. Something has } \\
\text { changed in their appearance. The smarter } \\
\text { to preen, his clothes match the girls in the } \\
\text { city. Trendy and sexy. } \\
\text { Panting, Ibu Aisyah put her feet on the } \\
\text { pedestrian bridge that crosses the Amandit } \\
\text { River. The bridge connects Loklahung } \\
\text { with Manakili. It used to be made of rotten } \\
\text { wood and some of it was broken. Now, it } \\
\text { has been transformed into a solid iron } \\
\text { bridge [31]. }\end{array}$ \\
\hline & & $\begin{array}{l}\text { The bridge was a } \\
\text { suspension bridge } \\
\text { made of wood, but } \\
\text { now has changed to } \\
\text { iron construction. }\end{array}$ & \\
\hline & & $\begin{array}{l}\text { Dayak Meratus } \\
\text { community used to use } \\
\text { the river for bathing } \\
\text { purposes, now public } \\
\text { bathrooms are } \\
\text { available. } \\
\text { The entry of electricity } \\
\text { to the Meratus Dayak } \\
\text { village is due to the } \\
\text { construction of a dam }\end{array}$ & $\begin{array}{l}\text { It really hasn't changed. Mawinei thought. } \\
\text { Only the lighting at night is more modern. } \\
\text { In the past, the long house only relied on } \\
\text { oil lamps, culuk, and one petromak for the } \\
\text { living room and special room for the } \\
\text { ritual. Now electric lights in the form of } \\
\text { neon make the atmosphere more lively. } \\
\text { This lighting happens because of the dam } \\
\text { built near their village [31]. }\end{array}$ \\
\hline
\end{tabular}

\subsection{Supporting Factors and Challenges of Cultural Transformation}

Supporting factors relate to internal and external factors that cause the transformation process to run easily.

Table 2. Supporting Factors of Dayak Meratus Cultural Transformation in the Novel Mawinei

\begin{tabular}{|c|c|c|c|}
\hline $\begin{array}{l}\text { Supporting } \\
\text { Factors }\end{array}$ & Indicator & Explanation & Citation \\
\hline $\begin{array}{l}\text { The internal } \\
\text { factor }\end{array}$ & $\begin{array}{l}\text { The awareness and } \\
\text { willingness of the } \\
\text { Dayak Meratus } \\
\text { community to move } \\
\text { forward } \\
\text { The rejection of the } \\
\text { traditions that have } \\
\text { been firmly held so } \\
\text { far } \\
\text { The influence of } \\
\text { modernization }\end{array}$ & $\begin{array}{l}\text { The rejection of } \\
\text { matchmaking at a } \\
\text { young age and the } \\
\text { mandate of } \\
\text { becoming a balian }\end{array}$ & $\begin{array}{l}\text { Their village is located on one of the } \\
\text { beautiful slopes of the Meratus Mountains } \\
\text { which is perfectly surrounded by wilderness. } \\
\text { Remote from anywhere. Its name is } \\
\text { Manakili. The radius with other villages is } \\
\text { about seven to ten kilos. The unfriendly } \\
\text { terrain had to be crossed to reach the nearest } \\
\text { school in Malaris [31]. } \\
\text { "Grandpa, I have absolutely no intention of } \\
\text { going against grandpa's wishes. I was } \\
\text { actually ready when my college was over. } \\
\text { So, please postpone talking about this until I } \\
\text { get my doctorate degree [31]. }\end{array}$ \\
\hline $\begin{array}{l}\text { The external } \\
\text { factor }\end{array}$ & & $\begin{array}{l}\text { Television shows } \\
\text { present an urban } \\
\text { lifestyle that has an } \\
\text { influence on young }\end{array}$ & $\begin{array}{l}\text { This wise Damang has also witnessed how } \\
\text { the way teenagers talk and interact in his } \\
\text { village are now starting to change. Maybe } \\
\text { this is the effect of satellite television }\end{array}$ \\
\hline
\end{tabular}




\begin{tabular}{|c|c|c|c|}
\hline $\begin{array}{c}\text { Supporting } \\
\text { Factors }\end{array}$ & Indicator & Explanation & Citation \\
\hline & $\begin{array}{l}\text { The entry of a new } \\
\text { belief, Islam }\end{array}$ & $\begin{array}{l}\text { people, both in } \\
\text { terms of dress, } \\
\text { speaking style, and } \\
\text { behavior. }\end{array}$ & $\begin{array}{l}\text { perched in several houses, due to the influx } \\
\text { of electricity into rural areas. In fact, there } \\
\text { are a small number of residents who already } \\
\text { have long-distance talking devices. } \\
\text { Sophisticated right. [31] }\end{array}$ \\
\hline & & $\begin{array}{l}\text { The change of } \\
\text { kaharingan belief } \\
\text { which believes in } \\
\text { ancestral spirits as } \\
\text { protectors by } \\
\text { holding traditional } \\
\text { rituals to Islam in } \\
\text { Mawinei character }\end{array}$ & $\begin{array}{l}\text { Mawinei left the house of his mother and } \\
\text { adoptive brother holding his mukena } \\
\text { wrapped in prayer rugs. He had just finished } \\
\text { praying maghrib in together with Aisyah's } \\
\text { mother led by Kak Subhan. }\end{array}$ \\
\hline
\end{tabular}

The challenges are related to the obstacles to the transformation process that occurs in the Dayak Meratus community.

Table 3. Challenges of Dayak Meratus Cultural Transformation in the Novel Mawinei

\begin{tabular}{|c|c|c|c|}
\hline Challenge & Indicator & Explanation & Citation \\
\hline $\begin{array}{l}\text { The } \\
\text { strength of } \\
\text { tradition }\end{array}$ & $\begin{array}{l}\text { Dayak Meratus } \\
\text { community still holds } \\
\text { the } \\
\text { ceremony }\end{array}$ & $\begin{array}{l}\text { Dayak Meratus } \\
\text { community regularly } \\
\text { holds aruh ganal } \\
\text { events as a form of } \\
\text { gratitude for the } \\
\text { abundant harvest. }\end{array}$ & $\begin{array}{l}\text { "This year's harvest is very abundant. We } \\
\text { will hold aruh ganal as a form of gratitude } \\
\text { to the Almighty. Celebrate your return. All } \\
\text { residents of the long house in other villages } \\
\text { will be invited. Your old friends are coming. } \\
\text { Youths. Including your future husband." } \\
\text { Granny Janai smiled happily. [31] }\end{array}$ \\
\hline $\begin{array}{l}\text { the } \\
\text { rejection of } \\
\text { new beliefs }\end{array}$ & $\begin{array}{l}\text { At first the new belief } \\
\text { was rejected by the } \\
\text { community. }\end{array}$ & $\begin{array}{l}\text { Different rituals lead } \\
\text { to different } \\
\text { acceptance }\end{array}$ & $\begin{array}{l}\text { "Just three days back, you suddenly dared to } \\
\text { break a tradition! Don't forget the nuts in the } \\
\text { skin, Winei. You were born and raised with } \\
\text { rice in this house. One problem is not } \\
\text { solved, don't add another problem. } \\
\text { Understand?" said Angah Anjau, bitch. [31] }\end{array}$ \\
\hline
\end{tabular}

\section{Discussion}

The forms of cultural transformation and the driving factors and challenges in cultural transformation that have been shown in the previous table can be described as follows.

\subsection{Cultural Transformations}

\subsubsection{Religious System Transformation}

The Dayak Meratus religious system is a belief in ancestral spirits accompanied by religious ceremonies in the form of traditional ceremonies led by balian. The transformation of the Dayak Meratus religious system contained in the Mawinei novel is related to the treatment ceremony for the sick led by the balian, the Bawanang gratitude ceremony, the inheritance of balian figures, and religious behavior. So far, if there is a sick Dayak Meratus community, a healing ceremony for the sick is held led by a balian. In the ceremony, spell words that are believed to be able to heal the sick are recited, accompanied by offerings and 
the endless beating of drums. After the ceremony, it is believed that the patient will gradually recover.

At this time a treatment ceremony for the sick led by a balian slowly changing to a doctor's treatment. Some community leaders still believe in treatment by balian to treat illness due to supernatural things. For the body pain, they prefer a doctor to cure the pain. The following is a quote from the novel Mawinei that presents from balian treatment who turned to doctor's treatment.

"It's okay. We need a doctor." Acil Rati emphasized while stopping the weave, showing a serious attitude.

"We have balian, we don't need to study far...", said Angah Anjau again.

"For body pain, we need a doctor. Balian is special for invisible pain. Remember, remember the case of Winei's mother! When she was a baby, Mawinei was helped by the doctor on the advice of Balian." [31]

"Kadapapa, Angah ai. Kita perlu dokter." Acil Rati menekankan sambil menghentikan anyamannya, menunjukkan sikap serius.

“Kita punya balian, tidak perlu sekolah jauh-jauh....”, tukas Angah Anjau lagi.

"Untuk sakit badan, kita perlu dokter. Balian khusus untuk sakit tak Nampak. Ingat, ingat kasus ibunya Winei! Sewaktu bayi, Mawinei ditolong dokter atas saran balian jua." [31]

Within the Dayak Meratus community itself there is still a debate regarding the healing of the sick, either through balian or doctor's treatment. Most of the Dayak Meratus people still believe that balian in the healing ceremony of the sick is able to heal the sick, but in a different realm, namely curing the sick due to supernatural things. To cure the sick because of pain in the body, they have turned to medical treatment by using medical devices and more modern medicines. This shift of belief in balian treatment occurs because of the experience of healing the sick treated by doctors when balian is no longer able, such as the Mawinei birth which was handled by a doctor.

In the Dayak Meratus community there has also been a transformation of the religious system related to the Bawanang ceremony. The Bawanang ceremony is a traditional ceremony held regularly by the Dayak Meratus community as an expression of gratitude for the abundant harvest for a year. The ceremony was carried out on a big event by inviting not only local residents, but also residents around the village. The transformation was that outsiders were allowed to be involved in the Bawanang ceremony at the traditional house, balai. Previously outsiders were not allowed to participate in the ceremony. It used to be believed that if an outsider came along, there would be disaster, death, or disease.

The ceremony at the traditional house, is now starting to lose its sacred value. Freeing foreigners in and out of the ceremony. Whereas in the past, Mawinei remembers, not just anyone was allowed to enter their village as long as aruh ganal was held. Unless you have asked permission and spent the night the day before. Far in advance, the youths would stand guard and patrol for safety, preventing outsiders from entering their territory. Villagers are not allowed to travel during aruh event. If this rule is broken, they believe that disaster, death or disease will happen [31].

Upacara di balai adat, kini mulai luntur nilai kesakralannya. Membebaskan orang asing keluar masuk upacara. Padahal dahulu, Mawinei ingat, tak sembarang orang diperkenankan masuk ke kampung mereka selama aruh ganal digelar. Kecuali sudah minta izin dan bermalam sehari sebelumnya. Jauh-jauh hari, para pemuda akan berjaga-jaga dan berpatroli untuk keamanan, mencegah orang luar masuk ke wilayah mereka. Warga kampung pun tak diperkenankan bepergian selama aruh berlangsung. 
Jika ini dilanggar, mereka meyakini akan timbul bencana, kematian atau wabah penyakit [31].

The figure of balian in the belief of the Dayak Meratus tribe plays an important role because the balian as the leader of the ceremony to heal the sick and the implementation of the harvest festival in the long house [32]. Not all Dayak Meratus people can become a balian because the position of balian is passed on to a chosen person who has understood the customary rules of the Dayak Meratus. The position of balian as the highest position in the Dayak Meratus community is a position of interest. However, in Mawinei's novel at this time there is a rejection as the successor of balian because Kaayat's character has been influenced by a new belief. The following quote describes Kayaat's rejection of the balian position that was placed on him because it was contrary to his current beliefs.

"Geez, Awat. Please forgive me profusely. I'm actually flattered by the trust that was bestowed upon me since childhood. However, the customary principle can no longer be carried out. So... I can't afford to take this position. Even though Awat considers myself to be the chosen one, my faith cannot be neglected [31].

"Ampun, Awat. Mohon ampun yang sebesar-besarnya. Sungguh sebenarnya aku tersanjung dengan kepercayaan yang dilimpahkan semenjak kecil. Akan tetapi, prinsip adat tak dapat lagi kujalankan. Jadi ... aku tak sanggup mengambil posisi ini. Meski Awat menganggap diri ini sebagai yang terpilih, namun keyakinan hati tak bisa dilangkahi [31].

The transformation of religious systems is also related to behavioral changes in beliefs. In the novel before converting to Islam, the Mawinei character adheres to the belief in ancestral spirits by carrying out various rituals/traditional ceremonies led by balian. However, after converting to Islam, Mawinei began to leave a culture that is not in accordance with their current beliefs, for example covering their body, no longer using tapih, traditional cloth, as they used to; refuse to dance the babangsai dance, a traditional dance at the aruh ganal event; and refuse to put amulets as ward off misfortune at home that are hung on bedroom walls, under mattresses, hung from the kitchen ceiling, or under the dining table. The following quote is one of the examples of Maniwei's behavior change in protesting the amulets in the house.

"Burning these amulets, Ni!" said Mawinei without stopping his action.

"No, Mawinei! Don't do that, you'll get the consequence! Pamali, Pamali! Goddamn it!" Bidayuh screamed as she tried to catch his granddaughter's hand to prevent the burning that bled his heart [31].

"Membakar jimat-jimat ini, Ni!" sahut Mawinei tanpa menghentikan aksinya.

“Jangan, Mawinei! Katulahan kaina! Pamali, Pamali! Katulahan!” Bidayuh memekikmekik seraya berusaha menangkap tangan cucunya untuk mencegah pembakaran yang mendarahkan hatinya [31].

When she returned to his hometown in Manakili, a village on the slopes of the Meratus Mountains, Mawinei's character experienced a change in behavior related to his current beliefs. According to her, the amulets that are put in all corners of her house are against the doctrine of her religion. Therefore, she tried to throw away the amulets. However, her actions were opposed by her grandmother who still believed in the existence of amulets as protectors of the house. According to the beliefs of Mawinei's grandmother and some of the Dayak Meratus community, the act of throwing and burning amulets is prohibited/pamali. If this rule is broken, they believe that there will be a disaster.

\subsubsection{Knowledge System Transformation}


The transformation of Dayak Meratus knowledge system can be seen in the change of mindset of the characters who no longer adhere to tradition due to the development of their knowledge and modernization. When Mawinei goes through a tradition that is against her faith, she dares to refuse, even if in a subtle way so as not to offend people who still hold the tradition. Mawinei rejected the arranged marriage tradition and married at a young age because she wanted to pursue higher education. Mawinei is the type of woman who is already forward-thinking. If some of the girls in her village get married at a very young age, she wants to become a doctor so that later she can serve and help the people in her village.

"Grandpa, I can't live up to your expectations! I refuse this matchmaking!"

Lonely. No reply was heard. Even the wind died, reluctant to make a sound. Everyone was shocked. The young girl had dared to break the rules of the damang they respected in front of all the guests. Damang whose supernatural powers shake the earth, shake the sky. A shrewd Dayak swordsman and skilled in Mandau knowledge with unexpected powers, terrifies his opponents. His leadership abilities and wisdom are unquestionable. Not a single one dared to argue, if this magic damang willed. That's why, it really makes blood boil, seeing the recklessness of a teenager, against the will of the tribal chief, who incidentally is her own grandfather [31].

"Awat, aku tidak bisa memenuhi harapan pian! Aku menolak perjodohan ini!"

Sunyi. Tak terdengar sahutan. Bahkan angin pun mati, enggan timbulkan bunyi. Semua orang terperanjat. Gadis muda itu telah berani melanggar ketentuan damang yang mereka segani di hadapan seluruh tamu. Damang yang kesaktian ilmu baliannya menggetarkan bumi, mengguncang langit. Pendekar Dayak yang lihai kuntau dan terampil ilmu Mandau dengan kekuatan tak terduga, menakutkan lawan-lawannya. Kemampuannya memimpin dan kebijaksanaannya pun tak diragukan lagi. Tak sebait pun ada yang berani membantah, jika damang sakti ini berkehendak. Maka itulah, sungguh membuat darah tersirap, melihat kenekatan seorang jadis remaja, melawan kehendak sang kepala suku, yang notabene adalah kakeknya sendiri [31].

Mawinei's refusal was not immediately accepted by the community, especially since she is the granddaughter of a tribal chief. The tribal chief is a leader who is highly respected by the people. He is a figure who has been given a mandate by his citizens for mastering all traditions and prohibitions in society. Therefore, all orders and prohibitions issued by tribal chiefs are absolute so that no one dares to oppose them. However, Mawinei, armed with the knowledge she gained, dared to refuse because she wanted to help the people in her village when she became a doctor. The transformation of the public knowledge system also occurs in the health sector. In the past, the Dayak Meratus community relied on traditional ingredients derived from plants that were efficacious in curing disease. However, at this time they began to turn to medical treatment.

"But Grandma Lamiang's concoction is also effective," said Angah Anjau.

"The problem is, none of us have inherited Grandma Lamiang's medical knowledge to an advanced level. If Grandma Lamiang dies, who will replace her? So far, only Mawinei is comfortable and willing to memorize the recipe." [31]

"Tapi obat racikan Nenek Lamiang juga manjur, sergah Angah Anjau.

"Masalahnya, tidak ada di antara kita yang mewarisi ilmu pengobatan Nenek Lamiang sampai tingkat mahir. Lamun Nenek Lamiang mati, siapa ganti sidin? Selama ini, hanya Mawinei yang betah dan mau menghapal resep racikannya." [31] 
Some of the Meratus Dayak people have trusted doctors to heal the sick. They believe that there are already traditional herbs that used to cure diseases. However, not all diseases can be cured only with traditional herbs. Many diseases still need to be treated by a doctor. Moreover, the inheritance of knowledge about these herbs does not necessarily continue to the next generation. Not infrequently that knowledge is only mastered by the previous generation, while the current generation is no longer in control. This is caused by various things, including the aspect of inheritance or specialization.

\subsubsection{Livelihood System Transformation}

Nature is a place for the Dayak Meratus to depend on for their daily needs. For them, the natural resources in their area have provided all the necessities of life. Therefore, the livelihood of the Dayak Meratus tribe is related to the use of nature, for example farming and hunting. However, in Mawinei's novel at this time some of the Dayak Meratus people have switched to other jobs. In the story, their long-standing livelihood has not been able to meet all the needs of people's lives. If you want to help and change the condition of society for the better, there have to be a Dayak Meratus figure who also has the profession. An example of the work described in the novel is in the realm of public health. If so far balian is the only one who can be relied on in curing disease, in the novel there have to be a doctor who treats disease.

According to her teacher, Setiawan, if you want to be smart in helping and treating sick people, you must become a doctor. Not balian. To become a doctor, you have to go to college. College costs a lot. The cost is similar to the value of the harvest of ten bulk of rice fields per year. If her performance is good, then Mawinei can get an achievement. But the cost of boarding, eating, drinking and college needs, borne by yourself.

When this ideal was expressed to her grandfather, the grandfather was silent. Mawinei understands. That's not a small amount of money. Even though Grandpa is still strong, it takes extra energy to work on the ten bulk of rice field. It is not easy for the Meratus people to cultivate such a large area of land using a shifting cultivation system. The results of other gardening were not much. Only if the price of rubber increases, they can earn more than usual [31].

Menurut Pak Guru Setiawan, kalau mau pintar menolong dan mengobati orang sakit, harus jadi dokter. Bukan balian. Untuk jadi dokter, harus kuliah. Kuliah perlu biaya banyak. Senilai hasil panen banih sepuluh borongan tanah pahumaan pertahunnya. Kalau prestasinya bagus, maka Mawinei bisa dapat prestasi. Tapi biaya kost, makan, minum dan keperluan kuliah, ditanggung sendiri.

Tatkala cita-cita ini diungkapkan pada kakeknya, sang kakek hanya diam. Mawinei paham. Itu jumlah biaya yang tidak sedikit. Meskipun kakek masih kuat bahuma, tapi untuk menggarap pahumaan sepuluh borongan, butuh tenaga ekstra. Tak mudah bagi bubuhan balai untuk mengolah tanah seluas itu dengan sistem ladang berpindah. Hasil berkebun lainnya pun tak seberapa. Hanya jika harga getah naik, mereka dapat penghasilan berlebih dari biasa [31].

Since childhood, Mawinei has dreamed of becoming a doctor. By becoming a doctor, she can serve people who need help in the health sector. Even though it costs a lot to become a doctor, Mawinei still fights for her dreams. The money he earns from helping with farming and tapping rubber is collected to pay for his education later. Mawinei has also refused to marry early according to the tradition of Dayak Meratus because she chose to continue her education. In addition to the medical profession, in Mawinei's novel it is also described that 
the forestry instructor profession has also changed the livelihood of the Dayak Meratus Tribe. The following is an illustration of Kayaat's tenacity to realize his goals.

"That means you will graduate soon. You'll have more time to help me in the fields. Soon it will be the season. We will have a lot of work, opening up new land."

"I'll help you on my vacation, Apang. After the holiday, I plan to register for junior high school in Loksado," said Kaayat earnestly [31].

"Berarti sebentar lagi lulus. Kau akan punya waktu lebih untuk membantuku di ladang. Sebentar lagi musim tugal. Kita akan banyak pekerjaan, membuka lahan baru."

"Kubantu pas liburan ya, Apang. Rencananya setelah libur, aku akan mendaftar SMP di Loksado,” kata Kaayat sungguh-sungguh [31].

Kaayat have refused to continue their work like the Dayak people in general, namely farming and becoming balian. He prefers to continue his education to college to be able to change the condition of the community. Forests in the Meratus Mountains, which are rich in natural resources, attract capitalists to manage for their profit. Therefore, Kayaat chose to become a forestry instructor so that forest management would not harm the Meratus Dayak community. The transformation of the livelihood system within the Dayak Meratus tribe occurs due to the increasing community's need for access to health and the importance of protecting the Meratus forest.

\subsubsection{Equipment and Technology Transformation}

With the influence of modernization, the equipment and technology systems of the Dayak Meratus have also changed. The most important living equipment needed by humans as a place to take shelter is a house. The typical house of the Dayak Meratus tribe is a long house called balai. Besides being used as a place to live, the long house is also used for traditional ceremonies and traditional meetings. The long house is in the form of a house on stilts inhabited by dozens of families. However, nowadays many families no longer live in the long house. They chose to build their own house. In addition to the house, in the aspect of clothing, which is also one of the human equipment, has undergone a transformation. In Mawinei's novel, this transformation can be seen in the change in the dress style of the young people of the Dayak Meratus Tribe. Their appearance already reflects the influence of modernization in the area. With the inclusion of electricity in the Meratus area, providing access to television shows. The urban lifestyle depicted in the program has an impact on lifestyles such as the way of dressing which tends to follow the current trends.

Si Balwin, Lida and Sarita are married and each have one child. While Rimbun, getting taller and beautiful. Something has changed in their appearance. The smarter to preen, his clothes match the girls in the city. Trendy and sexy.

That morning Rimbun looked sensual in a pink t-shirt and blue lezzing pants, highlighting her beautiful curves. In fact, she used to wear a regular negligee or a dress [31].

Si Balwin, Lida dan Sarita sudah kawin dan masing-masing beranak satu. Sedangkan Rimbun, bertambah tinggi dan cantik. Ada yang berubah dari penampilan mereka. Semakin pintar bersolek, pakaiannya pun menyamai gadis-gadis di kota. Trendy dan seksi.

Pagi itu Rimbun terlihat sensual dalam kaos oblong spandek pink dan celana lezzing biru, menonjolkan lekukan indahnya. Padahal, dulu dia pakai daster biasa atau gaun terusan [31]. 
The transformation of equipment and technology can also be seen in the bridge facilities in the Meratus area. In the novel, in the past the bridge was a suspension bridge made of wood. Due to age and weather, it is not uncommon for the bridge to be damaged because the wood is rotten and broken so it is not safe to cross if it rains. However, now the wooden bridge has changed to a stronger bridge because of its iron construction. An illustration of this change can be seen in the following quote.

Panting, Ibu Aisyah put her feet on the pedestrian bridge that crosses the Amandit River. The bridge connects Loklahung with Manakili. It used to be made of rotten wood and some of it was broken. Now, it has been transformed into a solid iron bridge [31].

Tersengal, Ibu Aisyah menapakkan kakinya di jembatan penyebarangan yang melintang di atas Sungai Amandit. Jembatan itu menghubungkan Loklahung dengan

Manakili. Dulunya terbuat dari kayu-kayu lapuk dan sebagian jebol. Sekarang, telah menjelma menjadi jembatan besi yang kokoh [31].

Another facility that has also undergone changes is the existence of a public bathroom in the Meratus area. In the past, the Dayak Meratus community used the river for bathing purposes, now public bathrooms are available. In the novel, it is described that public bathrooms have been built by the Health Service. Another change that occurs with regard to living equipment is lighting. Before electricity entered the Meratus area, at night the lighting relied on oil lamps, petromax. However, since electricity entered the Meratus area there has been a change. Fluorescent lamps have replaced the existing oil lamps, petromax. In the quote it is described that the entry of electricity to the Meratus Dayak village is due to the construction of a dam.

It really hasn't changed. Mawinei thought. Only the lighting at night is more modern. In the past, the long house only relied on oil lamps, culuk, and one petromak for the living room and special room for the ritual. Now electric lights in the form of neon make the atmosphere more lively. This lighting happens because of the dam built near their village [31].

Benar-benar belum berubah. Batin Mawinei. Hanya penerangan di malam hari saja yang lebih modern. Dulu balai hanya mengandalkan lampu minyak, culuk, dan satu petromak untuk ruangan laras dan pamatang. Sekarang lampu listrik berupa neon membuat suasana lebih semarak. Ini berkat bendungan yang dibangun dekat kampung mereka [31].

Cultural transformation has occurred in the Dayak Meratus community today. This change can be seen in Mawinei's novel, which is related to religious systems, knowledge systems, livelihood systems, and systems of living equipment and technology. This change shows that the Dayak Meratus Tribe is now open to the outside world, especially to the influence of modernization.

\subsection{Supporting Factors and Challenges of Dayak Meratus Cultural Transformation in the Novel Mawinei}

After analyzing the cultural transformation that occurred in the Dayak Meratus community, it is necessary to further explore the supporting factors and challenges in the process of cultural transformation.

\subsubsection{Supporting Factors of Dayak Meratus Cultural Transformation}


The Dayak Meratus tribe firmly holds the tradition. The tradition has been passed down from the predecessors to the next generation. However, the tradition is slowly changing due to internal and external factors that support the transformation. The internal factor is the awareness and willingness of the Dayak Meratus community to move forward. This is indicated by the persistence in obtaining access to education up to the level of pursuing higher education. This persistence aims to assist in overcoming the problems of the Dayak Meratus community. So far, health issues have become a major problem that needs to be resolved. Mawinei's character since childhood has dreamed of becoming a doctor to help the community in the health sector because not all diseases can be handled by balian. Mawinei's persistence in pursuing an education can be seen in the following quote.

Their village is located on one of the beautiful slopes of the Meratus Mountains which is perfectly surrounded by wilderness. Remote from anywhere. Its name is Manakili. The radius with other villages is about seven to ten kilos. The unfriendly terrain had to be crossed to reach the nearest school in Malaris [31].

Kampung mereka terletak di salah satu lereng indah Pegunungan Meratus yang sempurna dikepung hutan belantara. Terpencil dari mana pun. Namanya Manakili. Radius dengan perkampungan lain sekitar tujuh sampai sepuluh kilo. Medan tak bersahabat itu terpaksa dilewati untuk mencapai sekolah terdekat di Malaris [31].

Access to education for Dayak Meratus children is not as easy as that of children in urban areas. Mawinei had to travel long distances and it was not easy to reach school. However, she and her friends continued to study to achieve their goals. Her persistence finally paid off and became a doctor. After becoming a doctor, she devoted her life to the people in her village. The job transformation occurred because of the persistence of the Dayak Meratus community to be able to overcome their life problems in the community, namely in the health sector.

Cultural transformation also occurs because there is a rejection of the traditions that have been firmly held so far. Traditions have been passed down from ancestors and used as guidelines in social life. This tradition is absolutely obeyed by members of the community. If someone breaks it, it is believed that there will be disaster or sanctions. However, at this time there is a refusal to continue the tradition that has been going on, for example refusing matchmaking at a young age and refusing to continue the mandate of becoming a balian. Mawinei's character refuses to be matched at a young age by his grandfather who is a balian, a character who is respected by his citizens. The refusal was caused by his desire to become a doctor.

"Grandpa, I have absolutely no intention of going against grandpa's wishes. I was actually ready when my college was over. So, please postpone talking about this until I get my doctorate degree [31].

"Awat, sama sekali tiada maksud hatiku menentang harapan Awat. Aku pun sebenarnya siap jika kuliahku sudah tuntas. Jadi, mohon ditunda dulu pembicaraan tentang ini sampai aku berhasil meraih gelar dokter [31].

The refusal of tradition was also carried out by the character Kaayat when he was given the mandate to continue in the footsteps of his predecessor to become balian. Not everyone can become balian. There are special criteria that put Kaayat selected by his predecessor balian to become balian because of his ability, firmness, and charisma. However, Kaayat refused to become a balian because of his desire to pursue higher education. In addition, the rejection was also caused by the beliefs he had held so far. While in college, he began to study Islam. According to him, if he later becomes balian, he must carry out traditional rituals that are contrary to his beliefs. 
In addition to internal factors, external factors also encourage cultural transformation, including the influence of modernization and religion that entered the Meratus area. Modernization that is growing rapidly today encourages the capitalist system. The capitalists use the natural resources in the Meratus forest not only to meet the needs of the community, but also to make a profit. Companies have entered the Meratus area which is rich in natural resources. Exploitation of the Meratus nature has occurred, resulting in changes in the economic system. Modernization has entered the Meratus area, followed by the entry of electricity and technology, namely long-distance communication tools. With the entry of electricity into the Meratus area, it has encouraged cultural changes in the lives of its people. Television shows present an urban lifestyle that has an influence on young people, both in terms of dress, speaking style, and behavior.

This wise Damang has also witnessed how the way teenagers talk and interact in his village are now starting to change. Maybe this is the effect of satellite television perched in several houses, due to the influx of electricity into rural areas. In fact, there are a small number of residents who already have long-distance talking devices. Sophisticated right. [31]

Damang yang bijak ini juga telah menyaksikan, betapa cara bicara dan pergaulan remaja di kampungnya kini mulai berbeda. Mungkin ini pengaruh televisi berparabola yang bertengger di beberapa balai, imbas masuknya listrik ke wilayah pedesaan. Bahkan, ada sebagian kecil warga yang sudah memiliki alat bicara jarak jauh. Canggih betul. [31]

With the entry of a new belief, namely Islam into the Dayak Meratus environment, there was a change in the religious system. The Dayak Meratus community adheres to the kaharingan belief which believes in ancestral spirits as protectors by holding traditional rituals. Since converting to Islam, Mawinei carry out Islamic religious rituals, namely salat, daily moslem prayer. The way she dresses and behaves is also adjusted to her current beliefs. She no longer carries out traditional rituals as before. Therefore, if there is a ritual or behavior that is not in accordance with her current beliefs, Maniwei will refuse. At first this caused a lot of opposition from other community members. However, in the novel some of the characters in the story also end up following Mawinei's beliefs.

Mawinei left the house of his mother and adoptive brother holding his mukena wrapped in prayer rugs. He had just finished praying maghrib in together with Aisyah's mother led by Kak Subhan.

When his feet hit the floor of the living room, his grandfather was already there.

"You pray, like dangsanak anum. Banjar people. Even your clothes are different now," said Damang Aban flatly, while compiling ancak, small basket to put offerings, preparing for the next week's aruh ganal event [31].

Mawinei meninggalkan rumah inap ibu dan saudara angkatnya sambil mendekap mukena yang dibungkus sajadah. Ia baru saja selesai sholat maghrib berjamaah dengan ibu Aisyah. Diimami oleh Kak Subhan.

Saat kakinya menginjak lantai laras, kakeknya ternyata sudah berada di situ.

"Kau sembahyang, seperti dangsanak anum. Urang Banjar. Pakaianmu pun sekarang berbeda," tegur Damang Aban datar, sambil menyusun ancak, persiapan aruh ganal satu minggu ke depan [31].

The cultural transformation of the Dayak Meratus tribe occurs because of the driving force, both from within the Dayak Meratus community itself and from outside. If the impetus comes from within, there has been a change in mindset to move forward so that people can overcome their life problems and rejection of existing traditions. Meanwhile, the driving force from the 
outside is the modernization and the influence of new beliefs that have entered the Meratus area.

\subsubsection{The Challenge of the Dayak Meratus Cultural Transformation}

In the Dayak Meratus culture, acculturation has occurred when a new culture influences the existing culture. Cultural transformation in the Dayak Meratus tribe did not happen immediately. There are challenges in the process of transforming the Dayak Meratus culture. The strong roots of the Dayak Meratus culture are one of the challenges in this transformation process. Traditions that have been passed down from predecessors cannot simply be eliminated. In the novel, the Dayak Meratus community regularly holds aruh ganal events as a form of gratitude for the abundant harvest. The show is still going on today despite some changes. If so far there have been no foreigners involved in the event, now foreigners may be involved in the ceremony. In the novel, Mawinei's character, who has embraced Islam, still wants to be involved in the ceremony even though she does not participate in dancing like she used to do. An illustration of the strength of the tradition of the ceremony which was held lively by inviting residents of the long house around the village can be seen in the following quote.

"This year's harvest is very abundant. We will hold aruh ganal as a form of gratitude to the Almighty. Celebrate your return. All residents of the long house in other villages will be invited. Your old friends are coming. Youths. Including your future husband." Granny Janai smiled happily. [31]

"Panen raya tahun ini sangat berlimpah. Kita akan mengadakan aruh ganal sebagai wujud rasa syukur pada Yang Maha Kuasa. Sekalian merayakan kepulanganmu. Seluruh warga balai di desa-desa lain nanti diundang. Teman-teman lamamu akan datang. Pemuda pemudi. Termasuk calonmu. "Nenek Janai tersenyum sumringah. [31]

Another challenge in the process of transforming the Dayak Meratus culture is also related to the community's rejection of new beliefs. Since embracing Islam, Mawinei has carried out the religious rituals she adheres to. If something goes against Islam, Mawinei will avoid doing it. When knowing that the house has been put by amulets, Mawinei tries to remove and dispose of the amulets because it goes against his beliefs. However, Mawinei's actions led to rejection from the community. They believe that this act breaks tradition and that disaster will occur later.

"Just three days back, you suddenly dared to break a tradition! Don't forget the nuts in the skin, Winei. You were born and raised with rice in this house. One problem is not solved, don't add another problem. Understand?" said Angah Anjau, bitch. [31]

"Baru tiga hari kembali, tiba-tiba kau sudah berani melanggar satu tradisi!. Jangan lupa kacang pada kulitnya, Winei. Kau lahir dan besar dengan beras di lulung balai ini. Satu masalah belum selesai, jangan menambah masalah baru lagi. Mengerti?" sergah Angah Anjau, judes. [31].

The strength of the Dayak Meratus culture does not make it influenced by outside. Along with the times and modernization in the Meratus area, there has been a cultural transformation within the Dayak Meratus Tribe. The transformation is driven by influences, both from within the community itself and from outside. However, the transformation process also experienced challenges so that it did not easily influence the traditions that had existed for generations. The challenge comes from the strong tradition and rejection of the culture that entered the Meratus area. 


\section{Conclusion}

The perception of the Dayak Meratus tribe as a tribe that has strong tradition is increasingly fading. The cultural transformation of the Dayak Meratus Tribe is something that is inevitable with the influence of modernization. In the novel Mawinei by Eva Liana, there has been a cultural transformation which includes the transformation of religious systems, knowledge systems, equipment and technology systems, and livelihood systems. The transformation of the religious system is related to the treatment of doctors who replace the treatment of the sick by balian; the presence of a foreigner in a ceremony to express gratitude in bawanang ceremony; rejection of the inheritance of balian figures, and religious behavior. The transformation of the knowledge system takes place when there is a change in mindset to move forward so that it can solve problems that exist in the Dayak Meratus community. The transformation of the livelihood system can be seen in the change in livelihoods that have so far relied on the use of nature to knowledge. Meanwhile, the system of equipment and technology has also undergone significant changes, in the form of housing, clothing, and infrastructure in the Dayak Meratus village environment.

The cultural transformation caused by the existence of driving factors, both from within the community, namely the willingness to get out of life's problems and rejection of tradition, as well as from outside, namely modernization and the entry of Islam. However, there are challenges, namely the strength of tradition and rejection of the culture that entered the Meratus area. Therefore, in the development of the Dayak Meratus culture, there has been a mixing between the Dayak Meratus culture and outside culture in an effort to maintain culture in the midst of modernization.

\section{References}

[1] D. Prabawani, B., Prihatini, A. E., \& Purbawati, "Economic Rationalities of Loksado Indigenous in a Redenomination Perspective," J. ILMU Sos., vol. 18, no. 1, pp. 1--16, 2019, [Online]. Available: https://doi.org/10.14710/jis.18.1.2019.1-16.

[2] A. Rafiq, "Relasi Dayak-Banjar dalam Tutur Masyarakat Dayak Meratus," Al-Banjari J. Ilm. Ilmu-Ilmu Keislam., vol. 12, no. 1, 2013, [Online]. Available: https://doi.org/http://dx.doi.org/10.18592/al-banjari.v12i1.451.

[3] A. Abdullah, A., Kissinger, K., \& Fithria, "Tumbuhan Berkhasiat Obat Masyarakat Dayak Meratus Balai Adat Cabai Desa Patikalain Kecamatan Hantakan Kabupaten Hulu Sungai Tengah," J. Hutan Trop., vol. 8, no. 1, 2020, [Online]. Available: https://doi.org/10.20527/jht.v8i1.8156.

[4] H. Hartatik, "Religi dan Peralatan Tradisional Suku Dayak Meratus di Kotabaru, Kalimantan Selatan,” Kindai Etam J. Penelit. Arkeol., vol. 1, no. 1, 2018, [Online]. Available: https://doi.org/10.24832/ke.v1i1.4.

[5] A. L. Tsing, "Healing boundaries in south Kalimantan," Soc. Sci. Med., vol. 27, no. 8, 1988, [Online]. Available: https://doi.org/10.1016/0277-9536(88)90235-3.

[6] J. C. Markey, T. L., \& Muller, "Days among the Meratus Dayak: Smoking trees for trinkets," Mankind Q., vol. 53, no. 2, 2013, [Online]. Available: https://doi.org/10.46469/mq.2012.53.2.1.

[7] R. Yayuk, "Jejak Austronesia pada Masyarakat Dayak Meratus di Kecamatan Hampang,” J. Penelit. Sej. DAN BUDAYA, vol. 5, no. 2, 2019, [Online]. Available: 
https://doi.org/10.36424/jpsb.v5i2.34.

[8] H. Hestiyana, "Leksikon Etnomedisin Tumbuhan Obat Tradisional dan Penggunaannya untuk Memperlancar Persalinan oleh Suku Dayak Meratus," GENTA BAHTERA J. Ilm. Kebahasaan dan Kesastraan, vol. 6, no. 1, 2020, [Online]. Available: https://doi.org/10.47269/gb.v6i1.100.

[9] S. Saefuddin, Nf., \& Maryadi, "Tradisi Pengobatan Batimung dalam Masyarakat Banjar dan Dayak Meratus di Kalimantan Selatan (Batimung Healing Tradition of The Banjarese and Dayak Meratus Community in South Kalimantan)," Naditira Widya, vol. 12, no. 2, 2018, [Online]. Available: https://doi.org/10.24832/nw.v12i2.307.

[10] A. Pratama, R. B., \& Nurcahyo, "Kajian Sosioreligi Nilai-Nilai Upacara Aruh Baharin Dalam Masyarakat Dayak Meratus Halong Kabupaten Balangan Sebagai Sumber Pembelajaran Nilai Berbasis Multikultural," AGASTYA J. Sej. DAN PEMBELAJARANNYA, vol. 9, no. 1, 2019, [Online]. Available: https://doi.org/10.25273/ajsp.v9i1.3640.

[11] N. Indrawati, "Refleksi Budaya Banjar dan Dayak dalam Novel Jendela Seribu Sungai Karya Miranda Seftiana dan Avesina Soebli (Kajian Etnolinguistik)," UNDAS J. Has. Penelit. Bhs. dan Sastra, vol. 16, no. 2, 2020, [Online]. Available: https://doi.org/10.26499/und.v16i2.2839.

[12] P. Raewal, F. I., \& Anggraini, "Ritual Masyarakat Banjar dan Dayak dalam Novel Jendela Seribu Sungai Karya Miranda dan Avesina: Kajian Antropologi," UNDAS J. Has. Penelit. Bhs. dan Sastra, vol. 17, no. 1, 2021, [Online]. Available: https://doi.org/10.26499/und.v17i1.1782.

[13] S. Subagya, A.R dan Suhita, "Transformation of Cultural Values in the Novel di Bawah Langit yang Sama by Helga Rif (Literary Anthropology Approach)," J. Aksis J. Pendidik. Bhs. dan Sastra Indones., vol. 3, no. 1, 2019, [Online]. Available: http://journal.unj.ac.id/unj/index.php/aksis/article/view/12151.

[14] S. R. Choudhury, "Women and cultural transformation: The politics of representation in the novels of Bankimchandra chattopadhyay," Rupkatha J. Interdiscip. Stud. Humanit., vol. 12, no. 2, 2020, [Online]. Available: https://doi.org/10.21659/rupkatha.v12n2.07.

[15] C. Vitharana, S., \& Abeysinghe, "Transformation of Political Culture in PostIndependent Sri Lanka: Conceptual and Empirical Overview," Tech. Soc. Sci. J., vol. 18, no. 1, pp. 579-592, 2021, [Online]. Available: https://techniumscience.com/index.php/socialsciences/article/view/2926.

[16] A. Yusoff, M. A., Sarjoon, A., Hussin, N., \& Ahmad, "Analyzing the Contributions of the Sri Lanka Muslim Congress and its Founder-Leader to Muslim Politics and Community in Sri Lanka," Soc. Sci., vol. 6, no. 4, 2017, [Online]. Available: https://doi.org/10.3390/socsci6040120.

[17] D. S. Ababneh, "The transformations of narrative \& cultural systems in the novel 'Dafater al-Tufan' written by Sameeha Khrays," J. Hum. Sci., vol. 25, 2015, [Online]. Available: https://doi.org/10.12785/jhs/20152512.

[18] A. V. N. P. Astuti, "Representation of an Asian-Australian Gay in Hsu-Ming Teo's Behind the Moon," J. ILMU Komun., vol. 15, no. 1, 2018, [Online]. Available: https://doi.org/10.24002/jik.v15i1.1546.

[19] B. Merriman, "Duels in the European Novel: Honor, Reputation, and the Limits of a Bourgeois Form," Cult. Sociol., vol. 9, no. 2, 2015, [Online]. Available: https://doi.org/10.1177/1749975514561804.

[20] J. Gosling, "Will we know what counts as good leadership if Things Fall Apart? 
Questions prompted by Chinua Achebe's novel," Leadership, vol. 13, no. 1, 2017, [Online]. Available: https://doi.org/10.1177/1742715016680675.

[21] A. Andeweg, "Novels as Social Media: How Literature Helped Shape Notions of Sexual Liberation," Sex. Cult., vol. 21, no. 2, 2017, [Online]. Available: https://doi.org/10.1007/s12119-017-9419-9.

[22] A. S. Hilmi, "Perspektif Gender dan Transformasi Budaya dalam Novel Indonesia Berwarna Lokal Jawa. Jurnal Riksa Bahasa,” J. Riksa Bhs., vol. 1, no. 1, 2015, [Online].

Available: https://ejournal.upi.edu/index.php/RBSPs/article/download/6349/pdf.

[23] C. Kluckhohn, Mirror for Man: The Relation of Anthropology to Modern Life. New York: Routledge, 2018.

[24] C. Geertz, The Interpretation of Cultures. New York: Basic Books, 1973.

[25] T. Riwut, Kalimantan Membangun Alam dan Kebudayaan. Yogyakarta: PT Tiara Wacana Yogya, 1993.

[26] Y. Maunati, Identitas Dayak: Komodifikasi dan Politik Kebudayaan. Yogyakarta: LKiS, 2006.

[27] N. K. Ratna, Antropologi Sastra: Peranan Unsur-Unsur Kebudayaan dalam Proses Kreatif. Yogyakarta: Pustaka Pelajar, 2017.

[28] S. Endraswara, Metodologi Penelitian Antropologi Sastra. Yogyakarta: Penerbit Ombak, 2013.

[29] Koentjaraningrat, Pengantar Antropologi II: Pokok-Pokok Etnografi. Jakarta: PT Rineka Cipta, 1998.

[30] N. K. Ratna, Teori, Metode, dan Teknik Penelitian Sastra. Yogyakarta: Pustaka Pelajar, 2012.

[31] E. Liana, Mawinei. Banjarbaru: Penerbit Zukzez Express, 2017.

[32] D. Damayanti, Meratus, Nyanyi Sunyi di Pegunungan Borneo. Yogyakarta: Lamalera, 2016. 